\title{
MYCENA JUNIPERINA (AGARICALES, BASIDIOMYCOTA), NEW FOR THE POLISH AND CENTRAL EUROPEAN MYCOBIOTA
}

\author{
Marek Halama, Piotr Chachula \& Ryszard Rutkowski
}

\begin{abstract}
Mycena juniperina Aronsen was collected in March 2013 in the Origano-Brachypodietum association from trunks of living Juniperus communis in the Pieniny Mts (S Poland). The species is described and illustrated based on Polish specimens, its ecology and general distribution are outlined, and it is compared with similar species: M. meliigena (Berk. \& Cooke) Sacc., M. pseudocorticola Kühner, and others.
\end{abstract}

Key words: Tricholomataceae, Mycena cupressina, wood-inhabiting fungi, Polish mycobiota, Pieniny National Park, Carpathians, Poland, Europe

Marek Halama, Museum of Natural History, Wrocław University, Sienkiewicza 21, 50-335 Wrocław, Poland; e-mail: marek.halama@ uni.wroc.pl

Piotr Chachuła, Pieniński Park Narodowy, Jagiellońska 107B, 34-450 Krościenko nad Dunajcem, Poland

Ryszard Rutkowski, Wspólna 194, 34-331 Świnna, Poland

\section{INTRODUCTION}

Mycena juniperina Aronsen was originally described from material from the west bank of the Oslo fjord in southern Norway (Aronsen 1996). Together with M. conicoalba M. Villarreal \& EsteveRav., Mycena cupressina Antonín \& Maas Geest., M. meliigena (Berk. \& Cooke) Sacc., M. pseudocorticola Kühner, M. supina (Fr.: Fr.) Quél., and $M$. venustula Quél. it belongs to section Supinae Konrad \& Maubl., characterized by a corticolous habit, globose to subglobose, smooth, amyloid basidiospores, clavate to irregularly shaped cheilocystidia with evenly or unevenly spaced, short to very long and flexuous excrescences, the absence of pleurocystidia, and warty or diverticulate elements in the cortical layer of the pileus and stipe (Maas Geesteranus 1992; Robich 2003).

Macroscopically, M. juniperina is marked by its pale brown or yellowish brown color. Its microscopic characters show a resemblance to the widely distributed European (and North American) species M. meliigena and M. pseudocorticola, but those differ in the color of the lamellae, pileus and stipe (Miersch et al. 2004; Aronsen 2008) and grow almost exclusively on bark of frondose trees (cf. Ludwig 2012b). Mycena cupressina has basidiomata similar in color but is said to differ from M. juniperina by having paler lamellae, smoother hyphae of the stipitipellis, cheilocystidia covered with generally unbranched, short, cylindrical excrescences, and growth on bark of Cupressus sempervirens or rarely Arbutus unedo (Robich 2003; Miersch et al. 2004; Friebes 2010; Ludwig 2012b). It appears to be a Mediterranean species (Antonín \& Maas Geesteranus 1998; Onofri 2005; Ludwig 2012b; Wilhelm, unpublished). Emmett et al. (2008) and Moreno and Esteve-Raventós (2008) consider M. juniperina and M. cupressina to be conspecific, however. This seems to us the most reasonable taxonomical concept at present and is followed here.

Most likely due to its small size and somewhat specialized habitat, $M$. juniperina was only discovered in the latter years of the $20^{\text {th }}$ century from Northern Europe. Undoubtedly it was reported earlier as the color form of Mycena meliigena from northernmost regions of Africa (Morocco, Middle Atlas Mts) (Malençon \& Bertault 1975; cf. Robich 2003, 2009). It was subsequently reported from 


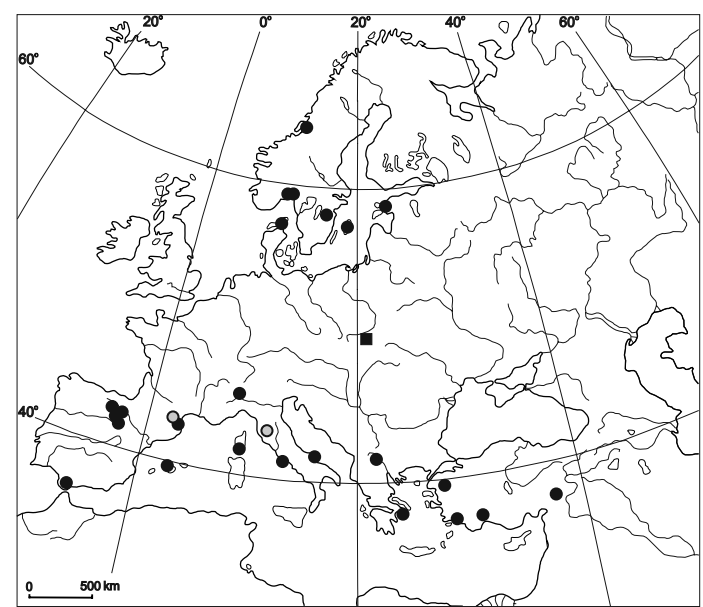

Fig. 1. Distribution of Mycena juniperina Aronsen in Europe (based on available literature data and reliable WEB sources): circle sign - previously known localities (black - indicated as M. juniperina, grey - reported as M. cupressina), square - new locality in Poland.

Sweden (Kummer \& Miersch 2001; Læssøe 2005; Krikorev 2008), Denmark (Læssøe 2005), Italy (Robich 2003), Spain (including Balearic Islands; Moreno \& Esteve-Raventós 2008; Pérez-DeGregorio i Capella et al. 2009; Salom \& Siquier 2011) and Turkey (Doğan \& Karadelev 2006; Sesli \& Denchev 2008; Doğan et al. 2011). It was noted from Estonia (Aronsen 2008; Anonymous 2013), France (including Corsica; Moreau et al. 2007; Aronsen 2008; Fridlender \& Louis 2010; Wuilbaut 2012), Greece (Konstantinidis 2012), and an imprecisely specified locality in the Former Yugoslav Republic of Macedonia (Karadelev, unpublished). Recently we discovered a new locality of this rare fungus in Pieniny National Park in southern Poland (Fig. 1). In this paper we describe the morphology of the first collections of $M$. juniperina from Poland, and compare their characters with published data. We discuss similar taxa and evaluate the ecology of the species.

\section{MATERIAL AND METHODS}

The description of macroscopic features is based on fresh material specified below. Microcharacters of basidiomata were observed with a Nikon Eclipse E-400 light microscope fitted with a Nikon digital camera
(DS-Fi1). All microscopic structures were observed in dried material. Free-hand sections of rehydrated pieces of basidiomata were examined in $5 \% \mathrm{NH}_{3} \mathrm{H}_{2} \mathrm{O}$, Congo red and Melzer's reagent. Image-grabbing and biometric analyses were done with NIS-Elements D 3.1 imaging software. Dimensions of microcharacters are given as (minimum) average \pm standard deviation (maximum), and additionally in the form of the main data range (5-95 percentile values). The $\mathrm{Q}$ value refers to the length/width ratio of basidiospores. Basidiospore size measurements were made from randomly selected mature spores, measured without the hilar appendix. Length of basidia was measured excluding sterigmata. Statistical computations employed Statistica software (StatSoft). Morphological terminology follows Vellinga (1988). Nomenclature of plant communities follows Pancer-Koteja et al. (2004). Details of the microcharacters were drawn freehand, with exact proportions and general shapes traced from photographs. The collections studied are deposited in the herbarium of the Museum of Natural History, Wrocław University (WRSL).

Specimens eXamined: 1 - POLAND, Pieniny Mts: Podskalnia Góra Mt., on trunk of living Juniperus communis (directly on bark), found from base up to $0.5 \mathrm{~m}$ height, 10 March 2013, leg. P. Chachuta; 2 - Popieska, on trunk of living Juniperus communis (directly on bark), found from base up to $0.6 \mathrm{~m}$ height, 2 March 2013, leg. P. Chachuta; 3 - Wielki Cisowiec Mt., on trunk of living Juniperus communis (directly on bark), found from base up to $0.6 \mathrm{~m}$ height, 2 March 2013, leg. P. Chachuła.

\section{RESULTS AND DISCUSSION}

\section{Mycena juniperina Aronsen}

Persoonia 16(2): 257. 1996. - Mycena cupressina Antonín \& Maas Geest., Persoonia 16(4): 545. 1998. Mycena corticola sensu Malençon \& Bertault, Flore des champignons supérieurs du Maroc. 2: 246-248. 1975 p.p. ('formes ocracées ou jaunatres').

ILLUSTRATIONS: Robich (2003: 654 as Mycena cupressina, 658), Læssøe (2005: 56), Roux (2006: 575 as Mycena cupressina), Aronsen (2008: photo. 1-10), Krikorev (2008: 20, fig. 3), Kummer \& Miersch (2001: 33, fig. 4), Moreno \& Esteve-Raventós (2008: 228, fig. 12), Pérez-De-Gregorio i Capella et al. (2009: 5657), Ludwig (2012a: 218, figs 116.31, 116.32 as Mycena cupressina), Wuilbaut (2012: 1,9).

Basidiomata single to scattered. Pileus 1.7-6.1 $\times 0.8-2.6 \mathrm{~mm}$, hemispherical to parabolic, finally 
convex, occasionally somewhat depressed in center or with small papilla and campanulate, conspicuously sulcate, pruinose to white-puberulous or even \pm flocculose, pale brown or yellowish brown, often darker in center, with margin paler to whitish. Lamellae, $\mathrm{L}=7-10,1=1-9$, reaching stipe, fairly broad, somewhat ascending or arcuate to subhorizontal, edge concave to convex, broadly adnate with decurrent tooth, sometimes decurrent far down the stipe, pale yellowish grey or beige with the edge white-pruinose. Stipe $1.5-8.6 \times 0.1-0.9 \mathrm{~mm}$, cylindrical or somewhat widened below lamellae and sometimes also towards base, equal, curved, cartilaginous, fistulose, usually clearly pruinose to \pm flocculose, beige, yellow-ocher, yellow-brown to pale brown, regularly much darker towards base, base occasionally attached to substrate with a patch of radiating, fine, whitish fibrils (Fig. 2). Context very thin and delicate. Smell imperceptible. Taste not noted.

Basidiospores (6.8) $9.7 \pm 1.0(12.8) \times(6.8)$ $9.0 \pm 1.0(12.1) \mu \mathrm{m}, 8.0-11.6 \times 7.4-11.0 \mu \mathrm{m}$, $\mathrm{Q}=(0.8) 1.1 \pm 0.1(1.5), \mathrm{Q}=0.9-1.3(n=139)$, subglobose to globose, smooth, amyloid. Basidia $(19.8) 27.9 \pm 3.0(32.5) \times(6.2) 10.1 \pm 1.4$ (16.0) $\mu \mathrm{m}, 23.8-31.9 \times 8.0-11.7 \mu \mathrm{m}(n=44)$, clavate, 2-spored (infrequently 4 -spored), with sterigmata (6.2)-(14.1) $\mu \mathrm{m}, 4.1-13.1 \mu \mathrm{m}$ long, generally not clamped, sporadically inconspicuously clamped. Cheilocystidia (13.0) $22.9 \pm 5.4$ $(47.1) \times(4.1) 7.7 \pm 1.2(12.1) \mu \mathrm{m}, 16.2-31.2 \times$ 5.6-9.8 $\mu \mathrm{m}(n=151)$, forming a sterile band, clavate, covered with unevenly spaced, simple to branched, curved to tortuous, often irregularly shaped excrescences, generally not clamped, exceptionally inconspicuously clamped. Pleurocystidia absent. Lamellar trama dextrinoid, brownish vinescent in Melzer's reagent. Pileipellis a cutis made up of cylindrical to inflated, (1.8)-(10.3) $\mu \mathrm{m}$, 2.4-7.2 $\mu \mathrm{m}(n=101) \mu \mathrm{m}$ wide hyphae, clampless, covered with simple to furcate or branched, (0.5)-(13.3) $\mu \mathrm{m}, 1.4-7.4 \mu \mathrm{m}(n=101)$ long excrescences, which may grow to coralloid masses. Hyphae of stipitipellis (1.4)-(5.0) $\mu \mathrm{m}, 1.9-3.9 \mu \mathrm{m}$ $(n=77)$ wide, with abortive clamps or clampless, covered with \pm scattered cylindrical excrescences,
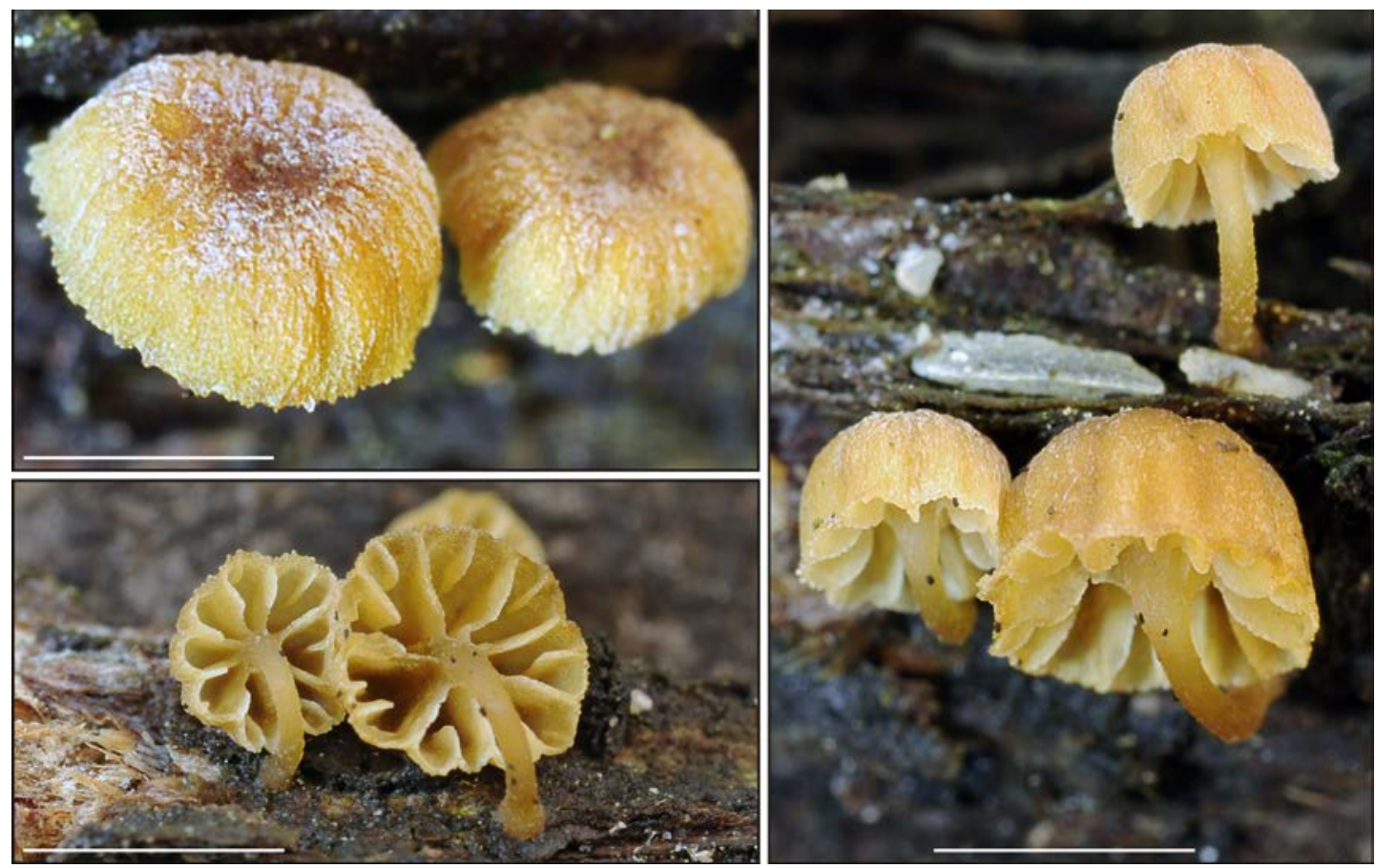

Fig. 2. Mycena juniperina Aronsen from the Pieniny Mts, Poland (WRSL-10032013; photo R. Rutkowski). Scale bars = 2.5 mm. 

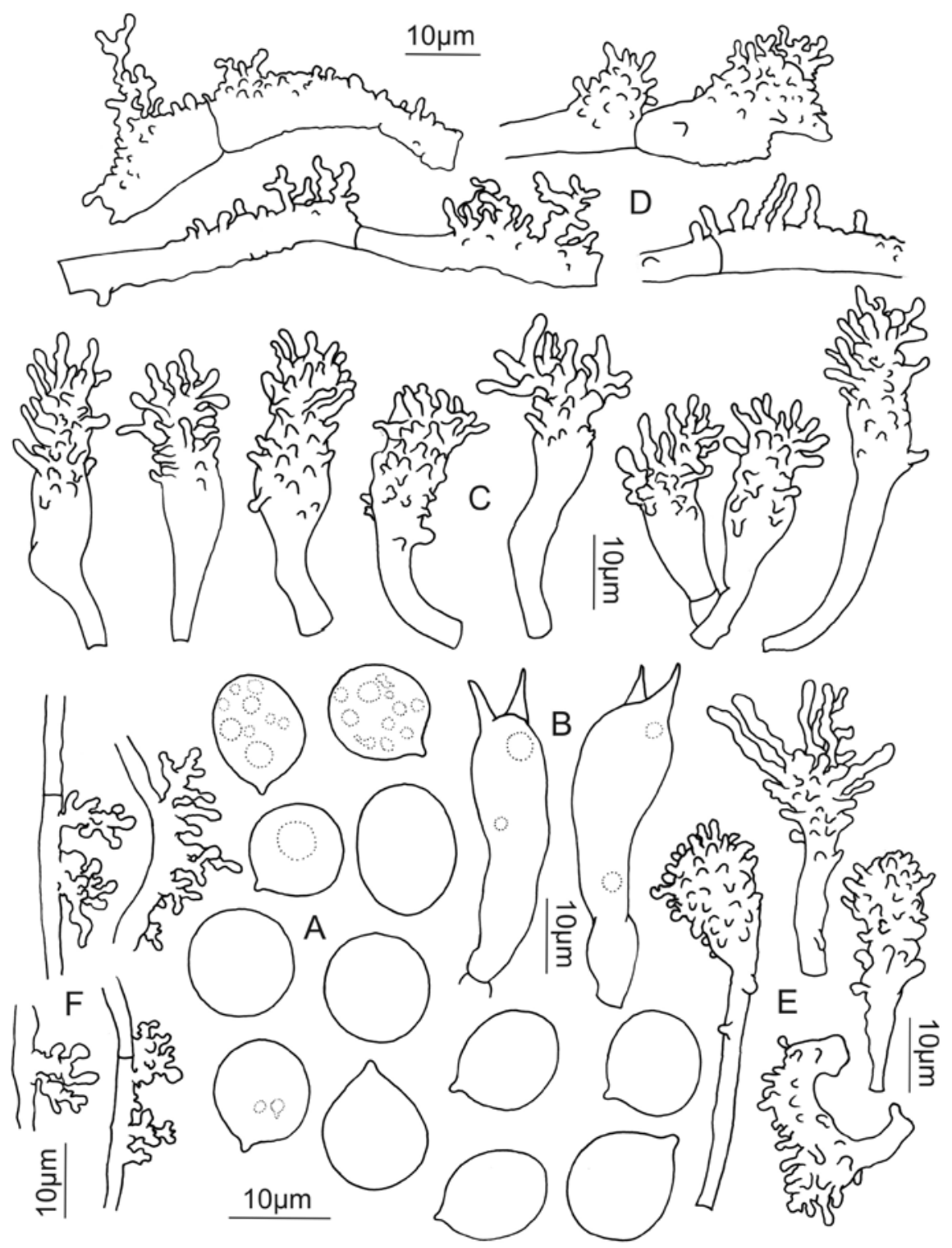

Fig. 3. Microcharacters of Mycena juniperina Aronsen: A - basidiospores, B - basidia, C - cheilocystidia, D - hyphae of pileipellis, E - caulocystidia, F - hyphae of cortical layer of stipe (WRSL-10032013; drawn by M. Halama).

(1.3) $-(9.2) \times(0.7)-(2.0) \mu \mathrm{m}, 1.6-7.2 \times 1.0-1.5 \mu \mathrm{m}$ $(n=46)$. Caulocystidia (terminal elements of stipitipellis) abundant, (12.5) $24.0 \pm 6.4(46.6) \times$ (4.7) $8.4 \pm 1.5(11.3) \mu \mathrm{m}, 14.3-35.6 \times 5.9-10.7 \mu \mathrm{m}$ $(n=66)$, clavate, sometimes irregularly shaped, densely diverticulate (Fig. 3).
NOTES ON MORPHOLOGY

Although the holotype of $M$. juniperina from Norway was not observed in this study, we consider the macro- and microcharacters exhibited by a number of Polish specimens to be consistent 
with those described by Aronsen (1996), as supplemented by others (e.g., Robich 2003). Our M. juniperina basidiomata were collected after a period of dry weather and night frosts. They were slightly dried, so their water content was lower than in a completely fresh state. In such conditions, most fungi have darker carpophores due to the higher concentration of pigments in their (partly drained) cells (cf. Fig. 2).

When Aronsen $(1996,2008)$ published his accounts of $M$. juniperina he described it as having four-spored basidia. Clamp connections were said to be present in all tissues. The Polish material of $M$. juniperina is almost lacking in four-spored basidia. The dominant two-spored basidia are smaller in our material, consistent with the four-spored ones described in the protologue. Two-spored (together with four-spored) basidia of $M$. juniperina were also reported by Robich (2003), Doğan and Karadelev (2006) and Pérez-De-Gregorio i Capella et al. (2009), and the occurrence of two- and four-spored forms in this species seems not to be an unusual phenomenon in Mycena (cf. Maas Geesteranus 1992). One would expect the two-spored condition to be accompanied by a corresponding difference in basidiospore dimensions (cf. Smith 1934). However, there is little if any difference in spore size between the Polish material and the available literature data. Since the analyzed basidia are somewhat smaller, it appears that the slight difference in spore size in our collections may be explained by the small amount of material available for spore formation. In the Polish specimens we saw no clamps in the pileipellis or the cortical layer of the stipe; at the base of basidia and cheilocystidia we observed them exceptionally. The literature devoted little attention to the presence and distribution of clamp connections in the species. According to Aronsen (2008) the common situation in the genus Mycena is that taxa with four-spored basidia possess clamps at the septa of the hyphae and at the base of basidia and cystidia, whereas two-spored forms are lacking in clamps (e.g., M. meliigena, M. pseudocorticola). There are exceptions: some species are known to produce clamps in both four-spored and two-spored forms (e.g., M. filopes, M. metata), and some constantly four-spored species (e.g., M. clavularis) consistently lack clamps. Furthermore, some species generally forming clamps (e.g., M. leptocephala) are sometimes devoid of clamp connections (cf. Maas Geesteranus 1992). These few examples suggest that there may be reasons not to overestimate the taxonomical value of clamps in the case of M. juniperina. The close similarity in all of the characters except for those mentioned indicates that the specimens we studied are evidently segregates from the typical (four-spored) forms of M. juniperina. Whether the discrepancy between the Polish material and the typical forms of the species is due to a genetic alteration or to the influence of a less favorable environment must remain unanswered for the present.

\section{Notes ON ECOLOGY, PERIODICITY AND DISTRIBUTION}

Mycena juniperina is a saprotroph, producing basidiocarps on the bark of living $J$. communis (Aronsen 1996; Robich 2003; Læssøe 2005; Emmett et al. 2008; Krikorev 2008, Pérez-De-Gregorio i Capella et al. 2009; this study). The first finds of $M$. juniperina in Poland were from the same substrate type. We observed several dozen basidiocarps growing on the bark of three separate living trunks (diam. $3-5 \mathrm{~cm}$ ) of $J$. communis, always at the base of these trees (partially moss covered) up to $c a 0.6 \mathrm{~m}$ above the ground. No other fungi shared the same substrate with this species except for some leprose and foliose lichen species. However, in recent years it has been shown that M. juniperina is able to inhabit other Juniperus species. It also grows on the bark of $J$. excelsa (Doğan \& Karadelev 2006; Doğan et al. 2011), J. oxycedrus (Pérez-De-Gregorio i Capella et al. 2009; Fridlender \& Louis 2010), J. foetidissima (Doğan et al. 2011) and J. phoenicea (Moreau et al. 2007; Konstantinidis 2012). There are also exceptional records from other hosts besides those within Juniperus, including Cedrus sp. (Malençon \& Bertault 1975), Cupressus sempervirens (Antonín \& Maas Geesteranus 1998 as M. cupressina), and the angiosperm Arbutus unedo (Antonín \& Maas Geesteranus 1998 as M. cupressina, Roux 2006 as 
M. cupressina, Moreno \& Esteve-Raventós 2008, Pérez-De-Gregorio i Capella et al. 2009, and Wilhelm 2012 as M. cupressina).

With a few exceptions there is little background information about the habitat availability and habitat use of $M$. juniperina in the known areas of its occurrence. In the Pieniny Mts (Wielki Cisowiec Mt., Głęboki Potok stream, Podskalnia Góra Mt.) we noted M. juniperina in xerothermic swards (Origano-Brachypodietum) from 530 to $700 \mathrm{~m}$ a.s.1. This association develops on south-facing, warm and dry slopes on soil rich in calcium carbonate (Pancer-Kotejowa \& Zarzycki 1976). From the literature it seems that $M$. juniperina is widespread in coastal localities in the northern and southern parts of its distribution range. This interpretation cannot stand for all of Europe, however, since the species is also reported from inland regions (cf. Fig. 1). Habitats with the occurrence of $M$. juniperina appear to be quite heterogeneous. In Northern Europe (e.g., Norway, Sweden, Denmark), J. communis is the only host, and M. juniperina's affinity for various (coastal) plant communities dominated by common juniper is clearly pronounced (Aronsen 1996, 2008; Læssøe 2005). At lower latitudes, for example in the south of France (LanguedocRoussillon region), M. juniperina was observed in a scientific garden on the slope of a very sunny hill where plants from different Mediterranean climates grow, including numerous specimens of J. oxycedrus (Fridlender \& Louis 2010), while in Corsica it was recorded in a maquis shrubland biome with $J$. phoenicea in the Clematido-Lentiscetum juniperetosum association (Moreau et al. 2007). In Turkey, Doğan et al. (2011) gave records of $M$. juniperina from different environments at 900-1200 m a.s.l. in pure and open stands of $J u$ niperus foetidissima and J. excelsa, J. foetidissima stands mixed with $J$. excelsa and Pinus nigra, various forest formations dominated by $J$. foetidissima and mixed with $J$. excelsa, J. oxycedrus, Abies cilicica, Acer. sp., Pinus nigra, P. latifolia, Quercus cerris and Q. coccifer, and (cf. Doğan $\&$ Karadelev 2006) from forest consisting mainly of Cedrus libani mixed with A. cilicica, Q. coccifera, J. excelsa and Phillyrea media.
It is known that fungi generally have more extensive ecological ranges than vascular plants do. In turn, fungal species have wider distribution areas than higher plants (Schröter 1880; Kalamees 1978). The nature of the distribution of fungal species is determined principally by the presence of suitable substrates and/or phorophytes with which fungi are trophically related; climatic conditions are mostly of secondary importance (Bisby 1933). Temperature, precipitation, humidity, length of season and other climatic factors affect the distribution of fungi, but it is not always easy to assess their exact influence (Bisby 1943). It is apparent that $M$. juniperina is not restricted to a specific set of seaside environmental conditions. The vast distance between recorded finds of $M$. juniperina shows that it has a wide distribution; it seems to be limited by moderate temperature but humidity may be equally or more important. The fungus appears to favor habitats with damp and cold but relatively mild climate of coastal regions at higher latitudes, as well as those with a bimodal regime of Mediterranean climate. Both at higher latitudes and in Mediterranean regions, M. juniperina can also occupy habitats far from the coast. The climate in the Pieniny Mts is milder than in other adjacent mountain ranges in Poland. Precipitation is relatively low. The south-facing hillsides where $M$. juniperina occurs are markedly warmer and more arid than the colder and more humid north-facing slopes and valley bottoms. During the growing season, rainfall is highest on northern slopes, but in winter the southern exposures also have abundant precipitation (cf. http://www.pieninypn.pl). The occurrence and local distribution of the species may also be (favorably) affected by the close proximity of the Czorsztyn-Niedzica and Sromowce Wyżne Reservoir Complex, as it is thought that these reservoirs alter the local mesoclimate within a $5 \mathrm{~km}$ range (e.g., Wróbel \& Zarzycki 2010). This suggestion is preliminary and needs to be verified.

Emmett et al. (2008) state that M. juniperina produces basidiocarps from late summer to autumn, while Aronsen (2008) mentions late autumn and early winter. Our observations are not consistent with this pattern but we note that most of the litera- 
ture data confirm that $M$. juniperina appears generally in the final quarter, with maximum incidence in November and December ( $c a$ 50\% records; Aronsen 1996; Robich 2003; Moreau et al. 2007; Krikorev 2008; Pérez-De-Gregorio i Capella et al. 2009; Doğan et al. 2011; Anonymous 2013). The rest of the finds are unequally distributed over the remaining months of the growing season: October (ca 10\% records; Aronsen 1996; Robich 2003; Pérez-De-Gregorio i Capella et al. 2009), May (ca 10\% records; Pérez-De-Gregorio i Capella et al. 2009; Fridlender \& Louis 2010; Doğan et al. 2011), March (ca 10\% records; Pérez-DeGregorio i Capella et al. 2009; this study), and to a small extent also over September, August, April, February and January (Aronsen 1996; Kummer \& Miersch 2001; Doğan \& Karadelev 2006; PérezDe-Gregorio i Capella et al. 2009; Konstantinidis 2012; Anonymous 2013). Since $M$. juniperina is so characteristic in the color and size of basidiomata, and also substrate specificity, it probably has not been much overlooked, but an occurrence early in the season or on a different phorophyte may draw less attention from macromycologists. Nor can we rule out the possibility that this species has spread only in recent years due to the unexpected development of favorable mesoclimatic conditions. In the Pieniny Mts $M$. juniperina does not seem to be extremely rare, but in Poland it should be classified at least as vulnerable and red-listed. Future collections should extend the present sparse observations so that this interesting species can be assigned its correct threat status in Poland.

ACKNOwLEDGEMEnTs. We are grateful to Bernadeta Pawlik (Kraków, Poland), Gabriel Moreno (Madrid, Spain), Jean-Jacques Wuilbaut (Mons, Belgium), Miguel Àngel Pérez-De-Gregorio i Capella (Girona, Spain), and Miguel Àngel Ribes (Madrid, Spain) for their kind help in completing the mycological literature, and to Dr. Jürgen Miersch (Halle, Germany) and the anonymous reviewers for constructive comments on the manuscript.

\section{REFERENCES}

ANONYMous 2013. eBiodiversity: a web interface for the taxa found in Estonia. [21 May 2013]. http://elurikkus.ut.ee.
Antonín V. \& MaAs Geesteranus R. A. 1998. Mycena $c u$ pressina, a new species of section Supinae from Italy. Persoonia 16(4): 545-547.

Aronsen A. 1996. Mycena juniperina, a new member of section Supinae from Norway. Persoonia 16(2): 257-259.

Aronsen A. 2008. A key to the Mycenas of Norway. [21 May 2013]. http://home.online.no/ araronse/Mycenakey.

BisBy G. R. 1933. The distribution of fungi as compared with that phanerogams. Amer. J. Bot. 20(4): 246-254.

BisBy G. R. 1943. Geographical distribution of the fungi. Bot. Rev. 9(7): 466-482.

DoĞAN H. H. \& Karadelev M. 2006. First record of Mycena juniperina from Turkey on a new host. Mycol. Balcanica 3: $77-79$.

DoĞan H. H., Karadelev M. \& IşıloĞLU M. 2011. Macrofungal diversity associated with the scale - leaf juniper trees, Juniperus excelsa and J. foetidissima, distributed in Turkey. Turkish Journal of Botany 35: 219-237.

Emmett E. E., Aronsen A., Læssøe T. \& Elborne S. A. 2008. Mycena (Pers.) Roussel. In: H. KNUdSEN \& J. Vesterholt (eds), Funga nordica. Agaricoid, boletoid and cyphelloid genera, pp. 352-387. Nordsvamp, Copenhagen.

Fridlender C. \& Louis J. 2010. Champignons et lichens des Pyrénées-Orientales et régions limitrophes. [21 May 2013]. http://mycologie.catalogne.free.fr.

FrIebes G. 2010. Die Gruppe der Rinden-Helmlinge (Mycena) in der Steiermark und ein Schlüssel der europäischen Arten. Joannea, Botanik 8: 43-58.

Kalamees K. 1978. A chorological review of the agarics occurring in Estonia. Scripta Mycol. 8: 83-134.

Konstantinidis G. 2012. New recordings of fungi in Greece. [21 May 2013]. http://www.manitari.gr.

Krikorev M. 2008. Notes on some rare or overlooked species of Mycena. Svensk Mykologisk Tidskrift 29(2): 16-27 (in Swedish with English summary).

Kummer V. \& Miersch J. 2001. Bericht über eine einwöchige mykologische Exkursion nach Gotland im Herbst 1999. Boletus 24(1): 29-41.

LÆSSøE T. 2005. En ny dansk huesvamp: Ene-Huesvamp (Mycena juniperina). In: J. Vesterholt (ed.), Uscedvanlige danske svampefund. Svampe 51: 56-57.

Ludwig E. 2012a. Pilzkompendium. 3. Abbildungen. Die übrigen Gattungen der Agaricales mit weißem Sporenpulver. Fungicon Verlag, Berlin.

Ludwig E. 2012b. Pilzkompendium. 3. Beschreibungen. Die übrigen Gattungen der Agaricales mit weißem Sporenpulver. Fungicon Verlag, Berlin.

MaAs Geesteranus R. A. 1992. Mycenas of the Northern Hemisphere. II. Conspectus of the Mycenas of the Northern Hemisphere. Koninklijke Nederlandse Akademie van Vetenschappen, Amsterdam. 
MalençON G. \& Bertault R. 1975. Flore des champignons supérieurs du Maroc. II. Travaux de l'Institut Scientifique Chérifien et de la Faculté des Sciences de Rabat, Série Botanique et Biologie Végétale 33: 1-540.

Miersch J., HardtKe H.J. \& RÖNSCH P. 2004. Bestimmungshilfen für einige europäische Rindenhelmlinge. Feddes Repert. 115(1-2): 43-49.

Moreau P.-A., Corriol G., Borgarino D., Aubel P., LAvoise C., Richard F. \& Selosse M.-A. 2007. Contribution à la connaissance des champignons de l'étage thermoméditérranéen Corse. II. Bulletin Semestriel de la Fédération des Associations Mycologiques Méditerranéennes 31: 9-31.

Moreno G. \& Esteve-Raventós F. 2008. Adiciones corológicas a la micobiota andaluza (Agaricomycetes). Boletín de la Sociedad Micológica de Madrid 32: 211-235.

ONOFri S. (ed.) 2005. Checklist dei funghi italiani. Basidiomycetes. Carlo Delfino, Sassari.

Pancer-Koteja E., Bodziarczyk J., Holeksa J., Piątek G., Różański W., SzWagrzyK J., Kaźmierczakowa R., Dubiel E., Perzanowska J., Wróbel I., Vončina G. \& ZARZYCKI J. 2004. Vegetation map of the Pieniny National Park, 1998-2001. In: R. KAŹMIERCZAK (ed.), Characteristics and map of plant communities of the Pieniny National Park. Studia Naturae 49: map.

Pancer-Kotejowa E. \& Zarzycki K. 1976. Umriß der Physiographie und der geobotanischen Verhältnisseder Pieninen samt Charakteristik ausgewählter Biotopen. Fragmenta Faunistyka 21(2): 21-49 (in Polish with German and Russian summaries).

Pérez-De-Gregorio i Capella M. À., Hermosilla C. E. \& Butrón J. L. P. 2009. Mycena juniperina Aronsen en España. Bollettino dell'Associazione Micologica ed Ecologica Romana 77-78: 54-59.
RoвICH G. 2003. Mycena d'Europa. Associazione Micologica Bresadola, Trento.

Roвich G. 2009. Revisione critica delle „Mycena” descritte da G. Malençon ed R. Bertault. In: J.-C. MaIre, P.-A. Moreau \& G. Robich (eds), Compléments à la flores des champignons supérieurs de Maroc de G. Malençon et R. Bertault, pp. 493-530. Confédération Européenne de Mycologie Méditerranéenne, Nice.

Roux P. 2006. Mille et un champignons. Édition Roux, SainteSigolène.

Salom J. C. \& Siquier J. L. 2011. Contribució al coneixement micològic de les Illes Balears (Espanya). XVIII. Revista Catalana de Micologia 33: 31-46.

SCHRÖTER J. 1880. Über die geographische Verbreitung der Pilze. Jahresber. Schles. Ges. Vaterl. Cult. 58: 160-162.

Sesli E. \& Denchev C. M. 2008. Checklists of the myxomycetes, larger ascomycetes, and larger basidiomycetes in Turkey. Mycotaxon 106: 65-67.

Smith A. H. 1934. Investigations of two-spored forms in the genus Mycena. Mycologia 26(4): 305-331.

Vellinga E.C. 1988. Glossary. In: C. Bas, T. W. Kuyper, M. E. Noordeloos \& E. C. Vellinga (eds), Flora Agaricina Neerlandica. Critical monographs on families of agarics and boleti occurring in the Netherlands. 1: 54-64. A. A. Balkema Publishers, Rotterdam.

WróBEL I. \& ZARZYCKI K. 2010. The influence of the Czorsztyn-Niedzica and Sromowce Wyżne reservoirs on the flora and vegetation of the Pieniny Mts. In: R. SoJA, S. KNUTElSki \& J. BodzIARCZYK (eds), Pieniny, dam, changes. Monografie Pienińskie 2: 131-152 (in Polish with English summary).

Wuilbaut J.-J. 2012. Les mycènes corticoles. Miscellanea Mycologica 102: 4-18.

Received 11 September 2013 